$\xi=-1$

\title{
The Role of Information Professionals in Protecting National History and Sovereignty
}

\author{
*Farah Wahieda Azman, Saiful Farik Mat Yatin, Nur Aliaa Amanina Mohd Aminuddin, \\ Nurhidayah Ahmad Dzarawi, Kamarul Azwan Azman, Mazlina Pati Khan \\ Faculty of Information Management, Universiti Teknologi MARA (UiTM), Selangor, Malaysia \\ *Corresponding author: * Farah Wahieda Azman: Faculty of Information Management, Universiti Teknologi MARA (UiTM), Selangor, \\ Malaysia \\ E-mail: farahwahiedaa45@gmail.com
}

\begin{abstract}
Protecting for sovereignty can be an effective tool in order to cope with relations between states, drawing boundaries of acceptable behavior. It's also a way of judging the actions taken from a state, whose owns ultimate power that always make the principle of sovereignty expendable. Information professional today play critical roles to ensure that state sovereignty would be strengthening and protecting them from external pressure. This paper highlights the need to pay more attention to the aspects of sovereignty that related with information professional roles and issues of Malaysian's neighboring country. Ignoring these aspects of sovereignty will lead to the issues that can threaten national sovereignty and peace.
\end{abstract}

Keywords: National history, Sovereignty, Information Professional

\section{Introduction}

The word 'sovereignty' in the government comes from the Arabic word (daulah), which means a political regime or power. Generally, sovereignty defined the concept of a preservation of the highest authority in the states. Sovereignty will not exist if there is no power in a region where it is administered. Sovereignty is also an exclusive right seeks full control of an administrative region, people or self. A person of the sovereign as the King is the formulation of general laws and not by any other order. In Malaysia, the King holds the highest authority and is supported by the Prime Minister. The sovereignty is the ultimate power to determine the law in certain country. Centred on sovereignty, it is indirectly linked to a country's security concerns.

The existence of a country depends on their sovereignty or ultimate power that is not unlimited and that there is no other power will be able to equivalent the power of a country. Furthermore, anyone should be complying with this power since if the country does not own the highest authority, its powers will easily be threatened and eventually it's also will threaten and disrupt national sovereignty itself. It's been proved that, the highest authority that can decisive their country should be free from the yoke of external forces because the country which is abide to external force can become a colony. In other words, a sovereign country is a country that has been independent and can determine the direction and destiny according to the dictates of their own without external influence or power. The principle of sovereignty does allow for the possibility, even necessity, of violating the integrity of another state [1]. Independence must also be derived from various aspects that are not only focused on the one area. The growth of a country and nation is closely related to independence was achieved in tremendous aspect, whether externally and internally.
In addition, people also play a crucial role to sustain state sovereignty-related about the obedience and loyalty for homeland safety Sovereignty and national history should be ensured in an assured without any foreign elements. The issue of defending the sovereignty and national security is a shared responsibility of entire citizens regardless of race, religion and power. Moreover, national sovereignty itself is the birth of moral values among people who applied it. Value citizenship also so closely and depend on each other with patriotism. Both of these values must be integrated then only it can develop the strength in defending the sovereignty and prosperity. In Malaysia, the sovereignty plays vital roles in order to ensure harmony and peace among the people is assured. Unity must be consistently being upheld in order to create a safe and peaceful atmosphere within a nation. It intended for contentment and protecting safety people of Malaysia is secure. At the same time, the country can achieve advancement easily and not simply subjugated by external elements. Adhering to the concept of sovereignty is one of the main conditions of the establishment of a country; a sovereign government is also closely related towards each other's. The government in a sovereign state should possess the highest integrity and unlimited. By this sovereignty government, it will be able to guide people towards a better direction. Issues such as misuse of power by the government will cause a lot of adverse effects and disrupt nation's security and sovereignty. These crises brought new attention to the issue of sovereignty. If the ruler themselves give fully sovereign towards their country, then people will follow it without any prejudice.

Unity must be consistently being upheld in order to create a safe and peaceful atmosphere within a nation. It intended for contentment and protecting safety people of Malaysia is secure. At the same time, the nature of the people who are always loyal to the king and their leaders and not the betrayal of the country would ensure the sovereignty of a country. 


\section{Discussion}

\section{Importance of Protecting National History}

Borders have traditionally been visible as a primary automobile for implementing behaviour and exclusion. Seen through the lens of the economic wisdom of globalization, with its stress on interdependency and quality, borders area unit frequently visible as a worth and time imposition. The border could be a strategic national quality. Border manages points, systems and techniques sit down astraddle deliver chains and tour pathways. Globalization has indeed already changed the manner within which borders characteristic and area unit perceived. The territorially linear better of borders is decease in favour of more and more connected borders. As a result of the earliest recorded times, rulers were regularly concerned to outline and defend the bounds in their authority, and to defend their frontiers towards invasion and conquest. Following to barriers in generation and communications, borders had been fluid, unwell-described and seldom monitored, other than by mistreatment mobile border patrols that had further in common with army units, and from time to time actually were army units. Borders were really frontiers and borderlands, in situ of strictly surveyed demarcations of dominion.

Today, borders retain their function of marking legal delineations of state dominion. At regulated ports of entry and exit, cross-border flows of individuals and merchandise occur, wherever states square measure ready to verify WHO and what has the correct, or gift, of entry or exit, and underneath in what conditions. However within the age of worldwide reciprocity, instead of being seen completely as a territorial barrier, we must always see the border as an area wherever sovereign states management the flow of individuals and merchandise in to and out of their dominion. In an aggressive and connected world atmosphere, states square measure additional actively encouraging seamless border passed motion based on intelligence-led assessments of border danger. Moreover the flow of version of the border, while in addition to abilities for period of time facts fusion and analytics, intelligencebased identification and focused on of excessive-chance border actions and speedy reaction social control and interdiction, really enhances border protection. That's because of the very fact such competencies allow border agencies to minimize their interventions in terms of low-risk border moves, and concentrate their posture whereby they're ready to create the foremost distinction. The government has tried to line out a replacement approach of brooding about sovereignty in an age of worldwide mutuality, with the concept of connected and networked borders.

\section{Roles of Information Professional}

Nowadays, in this digital era of information that is rapidly growing its can affected nation sovereignty in many ways. Similarly, in Malaysia with the constantly updated technology, there a lot of issue emerge and bring a lot of adverse effects such as ferocity, compilation of forbidden money, cybercrime, smuggling, stealth, cultivation and trafficking. Therefore, information professional should have responsible to ensure that the entire information created, disseminate and stored is protected. Many professionals with completely different background have their own responsibility for parts of knowledge and data management. One class of execs makes information, information, and data its primary focus.

These professionals come back from varied instructional backgrounds, together with liberal arts, science, records management and alternative disciplines. They add many various sorts of organizations and settings and have a spread of job titles and skilled labels. With the expertise that they pose in their own field they may able to contribute towards national history and sovereignty.

Increase society awareness on effect sharing their personal data in this globalization
Malaysia has implemented its own version of the Personal Data Protection Act (PDPA) in 2010. The act applies to any individual who processes and has control over or authorizes the processing of any personal data in respect of commercial transactions of the data user. The Act even applies to persons not established in Malaysia for example: foreign companies, if they use equipment in Malaysia for the processing of other person personal data. Examples of personal information are such as a person's name, address, phone number or email address. Sharing personal data without border can be harm against both parties either individually or nationally and in the meantime national sovereignty also undermined. To avoid this issue, society needs more exposure and awareness that might be conducted by information professional in various fields so that they are aware of this kind of threats. Extra enlighten should be adapt towards society because its shows that not all individuals in Malaysia is actually aware the existence of this threats. Majority of Malaysian is actually shared their data freely without limits with the social media as the platform. Undeniable, this information is helpful, but sometimes it can be used illegitimately or in a harmful way. This kind of behavior brings a lot harmful than it seen, behind this mechanism there is entity that been aiming us with the objective to conquer our nation without we realize it. Furthermore, develop a dynamic collection of information resources regarding national sovereignty and build deep understanding of society information sharing behavior is one of vital element to ensure the national history and sovereignty is being protected. It's important for information professional as they play critical role to gradually educate society until they aware of possible threats. Information professional should be mindful that if they found an existing global privacy policy in certain place, it may also need to be reviewed and customized to match the Malaysian requirements. For example, the Act requires personal data notices to be issued in both English and Malay. Plus, key personnel must be trained on the workings of the Act. Compliance with the Act is not possible if society do not understand the purpose of the Act or what they are required to do.

\section{Promote access to records fullest extent with the public interest}

The views of various data professions tend to be understood in terms of their manifestation within the practices of physical establishments. Over the past 2 centuries, a variety of knowledge establishments have evolved that play distinct roles at intervals society. These roles replicate the numerous ways that during which data is made, used, valued, preserved, and disposed of by people, organizations, and communities within the conduct of business, scholarship, learning, and private affairs. The knowledge skilled taught to promote access to records to the fullest extent in keeping with the general public interest however ought to observe any legal or prudent restrictions on the utilization of records, and not as a 'treasure' that solely resides in our repository. To acquire, manage and maintain documents and different materials that have historical importance for people, organizations and nations. An oversized a part of data skilled work is said to creating data accessible to users, progressively in digital format.

Plus, with the growth of the Internet and availability of vast amounts of information, Malaysian citizens should comply with the act created to ensure that their personal data is secured.

\section{Obtain empirical evidence of Information professionals mission such interventions pose to protect the national history and sovereignty}

In most organizations, the key professionals involved in knowledge management activities are human resource managers, process \& product developers, and information technologists. This assertion was partly corroborated by a bibliometric analysis of the field of knowledge management that showed that the field's popularity was largely due to the dominance of information technology applications [2] (Wolfe, 2003). However, lately, there has been increased interest in knowledge management activities by infor- 
mation professionals. Apparently, the mission such as interventions pose to sovereignty they're discursively built as strengthening the nation by improving its capability to perform its sovereign responsibilities.

\section{To provide evidence in each record that is not in the na- tional collection}

The term information expert is broad; the talents required for this profession also are numerous. Professional roles targeted on information management might be extraordinary to that of installed in any other roles. An information professional; will no longer be one type of role or ability set, but will in truth have some of specializations. For that reason, data expert can possess an expansion of various competencies, relying on the world in which the person is hired. The predominant roles being executed by means of data professionals in knowledge control programs encompass the design of the facts structure, improvement of the taxonomy, and content material management of the organization's intranet even as the minor roles include the supply of information for the intranet, amassing competitive intelligence, or offering studies services as requested with the aid of the know how management group.

An organization that wanted the records as an evidence to declare anything, they need to find the record. Here is the role as an information professional that they can apply in order to preserve the record that each country needed, as the situation for example it refer to the record that is not in the collection in their own country, they might take a look at the other library or the other archive such as British archive. Our information professionals might use the ILL Inter Library Loan with the other archive. They also need to manage the record in the archive as for the reference for the other user. Also, team operating, communication, networking and analytical skills were known because the most vital structure skills needed by info professionals to operate in information management programs whereas understanding of the information method among the business method, ability to use info technologies, and document management skills were known because the most vital needed competencies.

\section{Protecting the integrity of records}

Another role of Information Professional for protecting National history and sovereignty of Malaysia is protecting the integrity of records. The Information Professional has an obligation to ensure the valuable records regarding to the national history and sovereignty of Malaysia because it's really important as source of evidence both past and present in order to avoid any of cause of problems to the national history and sovereignty. It's really importance to protect the integrity of records especially the records that have the historical values or national importance such as the agreement between countries regarding to the disputed boundary cases like Malaysia and neighboring countries which is Singapore and Indonesia.

In order to ensure the integrity of records, an Information Professional has to work out several techniques such as establishing a chain of custody from record's issuer to a record's user. In order to protect the national history and sovereignty of Malaysia, an Information Professional must protect the integrity of records and guard the records either the digital records or paper records to avoid harmful records against defacement, alterations or theft. Besides that, an Information Professional also must protect the records to avoid harmful against physical damage by fire or excessive exposure to light, dampness and dryness. Although an equivalent technique will be applied to digital records, the properties of digital records compare the utilization of further techniques for making certain the integrity. It's as a result of digital techniques area unit accessible which will offer abounding stronger assurances than can existing techniques for paper records. It's extremely necessary in protective the digital records as a result of digital records area unit doubtless a lot of susceptible to forgery and change of state by an assailant with access to the archive's laptop and will add, delete, or alter records in an exceedingly wholesale fashion or create refined alterations that may be tough to observe by review

Furthermore, the role of Information Professional in protecting the integrity of records for protecting the national history and sovereignty of Malaysia because in order to ensure the records evidentiary value is not impaired in the normal course of rehabilitation, arrangement and use for both past and present.

\section{Preserve and make available records as source of evi- dence}

A constitution is a legal document that lays out the structure of government and the fundamental laws and principles governing a country and its people. The sovereignty of Malaysia is entrenched within the constitution and it has been called as pragmatic document that provides the framework for social, political and economic development that helps Malaysia thrive. Role of Information Professional for protecting National history and sovereignty of Malaysia is preserve and make available records as source of evidence. Records that have historical values or are of national importance will be transferred to the National Archives of Malaysia for permanent retention and preserved for future reference which related to the documents that pertaining to boundary matters. In order to preserve and make available records as source of evidence, Information Professional needs to do the research work on boundary disputes between Malaysia and neighboring country. Through the research, information professional needs to search through all records available and travel to places that are believed to hold the records of evidence and also preserve the records perfectly because everything that been keeps is really important as the evidence to the future. The records of old make peaceful resolution of conflicts a possibility by providing for negotiated settlements to boundary disputes for the purpose of asserting national sovereignty. In order to protecting national history and sovereignty, preserve and make available records as source of evidence is the key moments in sovereignty of Malaysia history and also throw light on milestones in history. Besides that, with all available records as source of evidence can avoid the disputed boundary cases between Malaysia and neighboring country which is Indonesia and Singapore like Pulau Sipadan, Ligitan and as well as Pulau Batu Putih (Pedra Branca) will never happen again.

\section{Protecting Malaysia Sovereignty Towards Neighboring Country}

State sovereignty implies responsibility, and therefore the primary responsibility for the protection of its folks lies with the state itself equally applied to Asian nation. The foundations of the responsibility to safeguard, as a guideline for the international community of states, depend on obligations inherent within the conception of sovereignty. Interdependency sovereignty has remarked the flexibility of a government to truly management activities among and across its borders as well as the movement of products, capital, ideas, and malady vectors.

External threats to the sovereignty of Malaysia occurred since the independence of Persekutuan Tanah Melayu in 1957 and the formation of Malaysia in 1963, Malaysia has been using a pragmatic approach in order to defend the country's sovereignty from outside threats. The method discussed is the use of pragmatic diplomacy reinforced the military's ability to deal with external threats. In addition, Malaysia also faced challenges coming from globalization such as foreign cultures, technologies, information and communications technology and foreign energy services. Borders country of Malaysia involves Singapore, Indonesia, Thailand and Philippine. Discussing about boundaries separating one country from another is a very complex issue. There are several issues regarding to the relationship between Malaysia with neighboring country such as Singapore, Indonesia, Thailand and Philippine. 


\section{Malaysia-Singapore relations}

According to Rusdi Omar [3], Malaysia and Singapore relations are distinctive and special as a result of factors like earth science, history, politics, ideology, economy, culture and quality. Asian nation and Singapore have stressed from time to time their economic interdependency and defense indivisibility. These factors generally have created tensions between these each countries once a series of problems emerged since 1965 till up to now, and still have difficulties in revolving these problems.

Thus, there are many current major problems that created the problematic of relationships between these 2 countries like water issue, Pulau Batu Putih (Pedra Branca), Malayan Railway (KTM) Land in Singapore and CIQ Issue, Land Reclamation, Air Space, Central Provident Fund withdrawals and Replacement of the Johor Causeway.

\section{Water Issue}

The first issue is water issue wherever Singapore has for the most part relied on installation from Malaya. Malaya provides Singapore with regarding half of its water and needs to renegotiate in between two agreements that originate to the 1960 and expire in 2011 and 2061. This issue happens once Malaya has argued that it's a right to review the value of raw water below this agreement whereas the Singapore Government has argued that Malaya lost its like hood to review costs within the mid-1980s once Malaya selected to not undertake the review.

This one is the major contentious issue facing Malaysia and Singapore. Water issue is about an agreement between Malaysia and Singapore regarding the supply of water through three agreements that have been entered into the 1927 Water Rights Agreement, the 1961 Water Agreement and the 1962 Water Agreement. When Malaysia's failure to supply water according to the agreement which was agreed means of Singapore's sovereignty was challenged and their governments must defend their rights. Water supply became the most contentious issue in the relationship when Malaysia began to apply pressure over the quoted water price.

\section{Pulau Batu Putih (Pedra Branca) Issue}

The second issue is Pulau Batu Putih (Pedra Branca) issue. Pulau Batu Putih is small island rocky island set 8 miles off the coast of Johor and twenty 8 miles off the coast of Singapore. It's associate degree island that Singapore has occupied and exercised full sovereignty over for over a hundred 30 years since the decennium with none protest from Asian country. This issue happen between Asian country and Singapore relations is as a result of the standing of Pulau Batu Putih (Pedra Branca) once in 1979, Asian country for the primary time revealed a replacement map including the island of Pedra Branca in its territory through 2 agreements that are entered into the Anglo-Dutch accord St Patrick's Day, 1824 and also the Crawfurd accord of August a pair of, 1824 Before this date, Singapore had occupied and exercised full sovereignty over the island for over one hundred 50 years since the decennium with none protest from Asian country wherever had showed that Pedra Branca as happiness to Singapore from previous Asian country maps. This issue conjointly happens once Asian country began to accuse Singapore of delay over the Pedra Branca issue and Asian country conjointly defendant Singapore of building new structures on Pedra Branca.

All of that was not true because Singapore had built no new structures on the island for the last 10 years and has been proved through painting Artist 1882 and a letter from the Acting State Secretary of Johor in 1953

Malayan Railway (KTM) Land in Singapore and CIQ Issue

Another issue of competition is within the context of territorial and national sovereignty of Singapore, involving the possession of the Malayan Railway Land and therefore the Customs, Immigration and Quarantine (CIQ). This issue happens between Asian country and Singapore thanks to Malayan Railway (KTM) Land in Singapore and therefore the standing of CIQ facilities in Tanjong Pagar. Asian country and Singapore determined to depart from the 1918 Railway Ordinance that each governments through some extent of Agreement (POA) signed in 1990 that is in agreement to collectively develop the land in Singapore through a joint stock company with Asian country effort of the equity state however Asian country signaled reluctance to commit itself to the previous arrangement throughout bilateral relations fermented in 1997.

\section{Malaysia-Indonesia relations}

\section{Borneo Confrontation}

Borneo confrontation also known as Indonesian-Malaysian was a violent conflict in year 1963 until 1966. During that time, the conflict was due to the Indonesian protest towards the creation of Malaysia. The creation of Asian nation was the unification of the Federation of Malaysia currently territorial dominion, Singapore and therefore the crown colony of British protectorates of island and district with the dominion conjointly referred to as British Borneo, currently East Malaysia in September 1963. Basically, the conflict enclosed Indonesia's policy of confrontation against Kingdom of The Netherlands Papua from March-August 1962 and therefore the sultanate Revolt in Dec 1962. From this incident initial, Indonesian attacks into East Malaysia relied heavily on local volunteers trained by the Indonesian Army.

With the path of time infiltration forces became more prepared with the inclusion of a bigger component of Indonesian forces. To prevent and interrupt Indonesia's growing campaign of infiltrations, the British responded in 1964 by launching their own underground operations into Indonesian Kalimantan under the code name Operation Claret. Coinciding with Sukarno announcing a 'year of dangerous living' and the 1964 race riots in Singapore, Indonesia launched a prolonged campaign of operations into West Malaysia on 17 August 1964, albeit without military success. A build-up of Indonesian forces on the Kalimantan border in December 1964 saw the UK commit significant forces from the UKbased Army Strategic Command and Australia and New Zealand arranged roulement combat forces from West Malaysia to Borneo in 1965-66.

\section{Malaysia-Thailand relations}

In order to protecting the National History and Sovereignty between Malaysia and neighboring country which is Thailand, there will also having the issues or challenges between Malaysia and Thailand relations. Malaysia-Thailand relations are referring to bilateral foreign relations between the two countries which is Malaysia and Thailand. Thailand has an embassy in Kuala Lumpur and consulate general offices in George Town and Kota Bharu. Malaysia maintains an embassy in Bangkok. Malaysia and Thailand usually co-operate in areas such as trade and investment, security, educations and vocational training, youth and sports, tourism, connectivity and socio-economic development in border areas. Thus, Malaysia and Thailand will discuss several key bilateral issues which created the problematic of relationships between these two countries such as one-sided affair, domestic issue and security issue.

Thailand is outwardly one among those countries that are getting more and more at risk of international scrutiny and responsibility. In keeping with Bajunid [4], Kingdom of Thailand these days is maybe facing its worst political and security crisis for a protracted time within the variety of an current insurgence in its southern most border provinces or Changwat Chaiden Pak Tai in Thai comprising the Muslim dominated provinces of Pattani, Yala and Narathiwat and components of Songkhla.

Malaysia's policy towards southern Thailand has always required a balance between the country's internal security and concern about a neighboring Muslim minority linked not only be religion but also ethnicity and culture. Security concerns eased with the surrender of the Communist Party of Malaya (CPM) in 1989, but re-emerged in late 2001 with the resumption of conflict in southern Thailand, and the surfacing of militant Islamic groups in Malaysia. When violence in southern Thailand resumed in late 
2001 and escalated dramatically in 2004, no external country was more affected than neighboring Malaysia. Security is close but low-profile cooperation on the situation in the Southern Provinces and tracking Communist guerrillas as well as Patani Malays militants. Besides that, there are several issues regarding to the security which are human trafficking, border security, and the unrest in southern Thailand. Human trafficking and the smuggling of contraband including drugs and petrol have flourished along the Thailand-Malaysia border for years. Malaysia-Thailand both faces security issues including the fight against terrorism, human trafficking and illegal smuggling. In light of recent concerns about violence and transnational crime, border issues are set to dominate talks between the two countries. Therefore, security issue dominated bilateral relations.

\section{Malaysia-Philippines relations}

\section{North Borneo dispute}

The dominion dispute is that the territorial dispute amongst the Federation of Asian country and also the Republic of the Philippines over varied jap a part of the state of Sabah, a territory called dominion before the formation of the Malaysian federation.

The Philippines, presenting itself as the successor state of the Sultanate of Sulu, retains a "dormant claim" on Sabah on the basis that the territory was only leased to the British North Borneo Company in 1878, with the sovereignty of the Sultanate and subsequently the Republic over the territory never having been relinquished. However, Malaysia considers this dispute as a "nonissue" as it interprets the 1878 agreement as that of cession and that it deems that the residents of Sabah had exercised their right to self-determination when they joined to form the Malaysian federation in 1963.

\section{Conclusion}

In invoking the 'responsibility to shield,' the resolution attracts on the principle that there are sovereign states square measure accountable and responsible to the community for the protection of their populations which the community will act to shield populations once national authorities fail to try and do so. the thought that sovereignty includes the responsibility to shield is commonly seen as a departure from the classic definition, however it really has deep historical roots. There square measure many recommendations which will be employed in order to shield Asian country sovereignty like offer instruction within the space of data acquirement. Teaching Information Literacy in the electronic environment is new way and exciting role for information professional. Developing and making courses for formal instruction within the discipline of knowledge attainment with the aim of encouraging freelance learners and significant thinkers to fulfil the challenges of the new modern era. The data skills area unit the foremost acceptable professionals to guide the team of individuals to find the answers to the challenges we have a tendency to face within the digital environments of electronic data and therefore the web. The data skilled have continuously been the consultants at teaching folks the way to use the tools to find that data in spite of format. Moreover, the mass media is a vital instrument in flow the knowledge to the users and therefore the mass media should be a lot of skilled in flow the knowledge concerning the people life and avoid the sensitive problems. Therefore, the knowledge can facilitate folks on the Asian nation additionally the neighboring countries to stay up with the developments and foster higher understanding and also the bilateral ties.

\section{Acknowledgement}

This paper was partially funded by:

1. Conference Support Fund, Institute of Graduate Studies (IPSis, UiTM)
2. Academic Development Trust Fund (TAPA), Faculty of Information Management, UiTM

\section{References and Notes}

[1] Grygiel, J. (2010). The Costs of Respecting Sovereignty. Orbis, 54(2), 268-283. https://doi.org/10.1016/j.orbis.2010.01.011

[2] (Wolfe, 2003).- missing

[3] Omar, R. (2014). An Analysis of the Underlying Factors That Affected MalaysiaSingapore Relations During the Mahathir Era: Discords and Continuity Rusdi Omar Thesis submitted for the degree of Doctor of Philosophy in the Discipline of Politics and International Studies S, (May), 372.

[4] Bajunid, O. F. (n.d.). The ongoing conflict in Southern Thailand and its international implications, 243-260.

[5] Berg, E., \& Kuusk, E. (2010). What makes sovereignty a relative concept? Empirical approaches to international society. Political Geography, 29(1), https://doi.org/10.1016/j.polgeo.2010.01.005

[6] Choo, C. W. (2000). Working with knowledge: how information professionals help organisations manage what they know. Library Management, 21(8), 395-403. doi:10.1108/01435120010342770

[7] Compliance and Enforcement. (2014). Sovereignty in the Age of Global Terrorism, 43-54. doi:10.1163/9789004299580_005

[8] Evans, Gareth and Sahnoun, M. (2001). The Responsibility to Protect. International Commission on Intervention and State Soverignty, VIII. https://doi.org/10.1080/1362369042000315069

[9] Fennessy, G., \& Burstein, F. (2007). Role of Information Professionals as Intermediaries for Knowledge Management in EvidenceBased Healthcare. Healthcare Knowledge Management Health Informatics, 28-40. doi:10.1007/978-0-387-490090_3

[10] Grygiel, J. (2010). The Costs of Respecting Sovereignty. Orbis, 54(2), 268-283. https://doi.org/10.1016/j.orbis.2010.01.011

[11] Marouf, L. (2004). Role and Contribution of Corporate Information Centers toward KM Initiatives: An Analysis of Managers Perceptions. Journal of Information \& Knowledge Management, 03(01) 9-25. doi:10.1142/s0219649204000638

[12] McGregor, A. (2010). Sovereignty and the responsibility to protect: The case of Cyclone Nargis. Political Geography, 29(1), 3-4. https://doi.org/10.1016/j.polgeo.2009.09.002

[13] Nolte, G. (2005). Sovereignty as Responsibility? Proceedings of the Annual Meeting ( American Society of International Law ), 99, 389-392.

[14] Rad, A., Shams, G., \& Naderi, B. (2009). Information Management and the Role of Information and Knowledge Managers: Managers'Perception. EDULEARN09 Proceedings, (July), 2504-2516. Retrieved from http://faculty.ksu.edu.sa/7338/pdf/40.pdf 